contribution to research on DNA tumour viruses, and one who certainly could have remedied this situation, had spoken on the occasion that gave rise to the book, and had neither contributed to it nor had his talk included. We are told only that Dulbecco "discussed the future of molecular biology"! Further, the occasion was deemed (as judged from pictures included in the book) to be a tribute to Joe Sambrook's role in the development of Cold Spring Harbor as a centre for the study of DNA tumour viruses, but, surprisingly, there is no contribution from him.

The "overviews", which take up about a quarter of the book, consist of four uncoordinated and stylistically variable chapters on SV40, polyoma, papilloma, adeno and herpes viruses. These are viruses with some claim to a cancer association, cancer being broadly and loosely defined. The chapter by Broker and Botchan on "retrospectives and prospectives" of papilloma viruses is very good indeed, but the others fail to measure up to this standard. They mostly give the impression that the authors couldn't see the wood for the trees. These chapters the promised update of "Tooze" - are followed by over 50 contributions from a variety of laboratories, with headings such as "Transcription", "Regulation of Transcription", "Processing and Translation", "Transformation" and so on, that attempt to provide the threads for linking together often quite disparate data, some novel, some raw and some rewarmed. The overall emphasis is on adenoviruses, undoubtedly reflecting the interests of Cold Spring Harbor Laboratory and the scientists associated with it. Here is it probably salutary to remind ourselves that the main clinical features of this virus are the respiratory infections, pharyngitis and conjunctivitis. That aside, some of the basic science presented, particularly on adenovirus, is very elegant, and the short article by P.A. Sharp, "Analysis of Splicing of mRNA Precursors In Vitro", alone makes it worth continuing as far as page 245. Much of the information given in the book appears in primary journals, however.

Overall, this discourse on DNA tumour viruses is a helpful catalogue of events and a good source of references. I can admire the occasional flashes of insight it provides. Its failures reflect the fact that scientists these days are generally "too busy" to pay much attention to the more global aspects of their work. Likewise editors. Further, like any work that focuses more on data than ideas, it will become rapidly dated. I was left to wonder why the publications department at Cold Spring Harbor Laboratory did not consider asking Tooze to update "Tooze".

Beverly E. Griffin is Professor of Virology at the Royal Postgraduate Medical School, Hammersmith Hospital, London W12 OHS, UK.

\section{Putting humanity in context}

\section{Ian Tattersall}

Another Unique Species: Patterns in Human Evolutionary Ecology. By Robert Foley. Longman:1987. Pp. 313. Pbk $£ 12.95$. To be published in the United States in December by Wiley, provisional price $\$ 32.95$.

IT is lamentable, if hardly surprising, that as our egocentric species has laboriously compiled its own autobiography over the past century or so, it has tended to depict itself not simply at the centre of the evolutionary stage but as occupying virtually the entire proscenium. One is thus refreshed by the title of Robert Foley's new book, Another Unique Species. Here is a work on human evolution that starts by calling attention to the fact that all species are unique, so our much-vaunted feeling of apartness simply serves to align us with the rest of nature in yet another way.

Inevitably, though, because Foley is concerned here with the evolutionary history of Homo sapiens, our species is perforce once more the star of the show. But then, that is in the very nature of autobiography, and indeed what gives this genre its peculiar fascination. What the author actually manages to do is to squeeze various other parts of nature into our story in something a little better than the few familiar cameo roles: the herbivores that were there to be hunted; the plants that were there to be gathered; the rocks that were waiting to be picked up, carried around and fashioned into tools.

Foley's purpose is, of course, rather broader than this: to integrate the story of early human evolution into the wider picture of the changing African biosphere, and to show that throughout their evolution humans have been subject to the same environmental constraints as other vertebrate species. He attempts to do this by examining the evidence, such as it is, for climatic and faunal change in Africa over the past several million years, and applying to it certain principles of evolutionary ecology, which might be characterized more accurately as a set of rules-of-thumb derived from empirical comparisons made across the modern fauna.

One problem that immediately arises is that, while what evidence we have indicates that climatic oscillation has clearly been the rule over the period in question, Foley's approach to evolution is strictly neo-darwinian and (despite his protestations) equally strictly adaptationist. There is thus a tension throughout the book between the relatively short-term ecological fluctuations Foley describes, and the necessarily long-term putative evolutionary responses by hominids with which he is clearly most comfortable. This is true even though he makes the crucial but generally overlooked observation that conditions promoting population fragmentation and coalescence - and hence hominid speciation and interspecies competition were rife in the Plio-Pleistocene. Laudably, though, he is not constrained by his view of speciation as a special case of anagenesis from speculating that the African Plio-Pleistocene harboured many more hominid species than are currently recognized.

Rapidly improving though it is, the human fossil record is rather too sparse to allow testing of most of the predictions Foley makes from his ecological principles. This results in a discussion that in the main is reminiscent of the just-so stories about human evolution that the rest of us have been telling for many years. The process does however throw up some interesting speculations - for instance that meat-eating among hominids may have begun in the context of seasonal dietary stress; or that the robust australopiths had a relatively specialized feeding strategy that was most successful in times of maximum species richness, while the most generalized Homo assumed the advantage in times of deteriorating environmental quality.

My main difficulty is in deciding for whom the book was written: it is obviously intended to be accessible to students, and offers background information clearly aimed at them. But it does not contain enough discussion of the human fossil record, or of palaeoenvironments, or of ecology to serve as a text in any of these areas. Perhaps it will find a niche as supplemental reading in general palaeoanthropology courses.

Ian Tattersall is Curator in the Department of Anthropology, American Museum of Natural History, New York 10024, USA.

\section{New in paperback}

- The Nemesis Affair: A Story of the Death of Dinosaurs and the Ways of Science by David M. Raup. Publisher is W.W. Norton, price is $\$ 6.95$ (the book comes out in Britain in October, price 55.95 ).

- The Age of Birds by Alan Feduccia. Publisher is Harvard University Press, price is $\$ 12.95, £ 10.50$. For review see Nature 290, 646 (1981).

- Perception and Communication by D.E. Broadbent, with a new foreword by Michael I. Posner. Publisher is Oxford University Press, price is $£ 15, \$ 26.95$. For review see Nature $\mathbf{1 8 2}$, 1,572 (1958).

- Power Production: What Are the Risks? by J.H. Fremlin, with a new postscript on the accident at Chernobyl. Publisher is Oxford University Press, price is $£ 6.95$. For review see Nature 316, 583 (1985). 